\title{
WAKAF UANG (Sebuah Alternatif dalam Upaya Menyejahterakan Masyarakat)
}

\author{
Fahruddin Ali Sabri \\ (Jurusan Syari'ah STAIN Pamekasan, jln. Pahlawan KM. 04 Pamekasan, email. \\ didin021@gmail.com)
}

\begin{abstract}
Abstrak
Kemiskinan dan kesenjangan sosial di Indonesia merupakan persoalan krusial yang kronis dan sulit untuk dipecahkan. Kemiskinan dan kesenjangan sosial cukup mengemuka di sebuah negara yang kaya dengan sumber daya alam yang melimpah. Lebih buruk lagi, negara yang diklaim miskin dan berpenduduk terbesar kelima dunia, ternyata dihuni mayoritas umat Muslim. Salah satu solusi alternatif dalam mengatasi persoalan kemiskinan dan kesenjangan sosial adalah dengan mengembangkan wakaf. Wakaf merupakan salah satu lembaga hukum yang berasal dari hukum Islam. Wakaf dilakukan oleh umat Muslim dalam rangka melaksanakan ibadah untuk Allah. Pelaksanaan wakaf harus memenuhi rukun dan syaratnya wakaf. Rukun wakaf ada empat yaitu adanya wakiff, harta yang akan diwakafkan, tempat di mana benda akan diwakafkan dan akad. Benda wakaf berdasarkan hukum Islam meliputi semua harta yang dimiliki oleh wakîf. Salah satu dari macam wakaf yang beberapa tahun belakangan ini dikenal oleh umat Muslim adalah wakaf uang. Wakaf uang akan dapat menjadi instrument ekonomi penting untuk menyelesaikan persoalan kemiskinan dan kesenjangan, sehingga masyarakat akan sejahtera.
\end{abstract}

\footnotetext{
Abstract

Poverty and social gap in Indonesia is a cronical crucial problem that is difficult to solve. The poverty and social gap are dominant in a rich country with the overbundance natural resource. The fact is worse that the country which is claimed as a poor and five biggest country in the world are inhabited by Moslems majority. One of alternative solutions in solving the poverty problems and social gap is by developing wakaf. Wakaf is one of laws that is from Islamic one. It is done by Moslems in performing worship to Allah. The establisment of wakaf must
} 
meet its pillars and requirements. Wakaf pillars consists of four, those are the existing of wakif, wealth which will be donated, a place where the things will be donated, and a contract. The wakaf things are based on Islamic law consisting all wealth owned by wakiff. One of wakaf things in recent years known by Moslems is money. The wakaf of money will be able to become an important economy instrument to solve the problems of poverty and gap in order to make the society will be prosperous.

\section{Kata Kunci}

Wakaf uang, nâzhir, wakîf, kesejahteraan

\section{Pendahuluan}

Wakaf merupakan bagian dari syarî́ah yang di satu sisi mempunyai fungsi sebagai ibadah kepada Allah dan di sisi lain wakaf juga berfungsi sosial. Wakaf termasuk salah satu wujud dari keimanan yang tinggi di antara sesama manusia. Wakaf adalah suatu lembaga Islam yang dapat dipergunakan bagi seorang muslim untuk mewujudkan dan memelihara hubungan manusia dengan Allah swt dan hubungan manusia dengan manusia lain dalam masyarakat.

Berkaitan dengan wakaf, al-Syâfi'î pernah berkata, "setahu saya tidak ada orang jahiliyah yang mewakafkan tanah dan rumahnya". Kemudian al-Nawâwî melanjutkan pernyataan imam alSyâfi'î dengan menyatakan bahwa wakaf adalah sebagian dari hal-hal yang dikhususkan untuk umat Muslim. ${ }^{1}$

Amalan wakaf sangat besar artinya bagi kehidupan sosial ekonomi, kebudayaan, dan keagamaan. Oleh karena itu, Islam meletakkan amalan wakaf sebagai salah satu macam ibadah yang amat menggembirakan. ${ }^{2}$ Dalam fungsinya sebagai ibadah, ia diharapkan akan menjadi bekal bagi kehidupan si waqîf. Pada hari kemudian, karena ia merupakan suatu bentuk 'amal jâriyah yang pahalanya akan terus mengalir selama harta wakaf itu dimanfaatkan.

${ }^{1}$ Wahbah al-Zuhayli, Figh al-Islâm wa Adillatuh (Mesir: Dâr al-Fikr, tt.), hlm. 156.

2 Ahmad Azhar Basyir, Hukum Islam tentang Wakaf, Ijarah, Syirkah (Bandung: PT alMa'arif, 1977), hlm. 7. 
Wakaf termasuk kategori sedekah jâriyah yang nilai pahalanya senantiasa mengalir selagi manfaatnya bisa dipetik. Dalam konteks inilah, maka para fuqahâ' mengemukakan hadits yang berbicara tentang keutamaan sedekah jâriyah sebagai salah satu sandaran wakaf. Seperti yang diriwayatkan dari Abû Hurayrah ra:

$$
\begin{aligned}
& \text { عن ابي هر يرة ان رسول الله صلى لله عليه وسلم قال : إذا مات ابن الآدم انقطع عنه عمله إلا }
\end{aligned}
$$

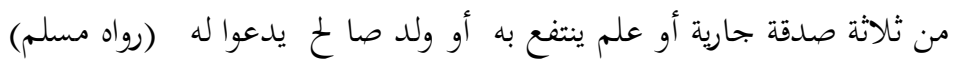

"Dari Ab̂̂ Hurayrah bahwa Rasulullah saw telah bersabda: Apabila meninggal manusia, maka terputuslah pahala segala amalnya, kecuali tiga macam, yaitu sedekah jariyah, ilmu yang bermanfaat, atau anak shalih yang selalu mendo'akannya". ${ }^{3}$

Hal tersebut mengakibatkan, dalam praktik pengamalan wakaf dewasa ini, tercipta suatu image dan persepsi tertentu mengenai wakaf. Pertama, wakaf itu umumnya berwujud benda tak bergerak, khususnya tanah. Kedua, dalam praktik, di atas tanah itu didirikan masjid atau madrasah. Ketiga, penggunaanya hanya terbatas pada apa yang menjadi isi pesan dari pemberi wakaf (waqîf).

Selain itu timbul pemahaman bahwa benda-benda wakaf tidak boleh diperjualbelikan, sehingga lembaga-lembaga perbankan tidak mau menerima tanah wakaf sebagai barang jaminan. Hal itu berakibat pada upaya untuk lebih mengembangkan dan menjadikan benda wakaf sebagai sumber pendapatan finansial menjadi terhambat dan tidak menemukan salurannya. Demikian pula dengan penggunaan tanah wakaf dari waqîf yang berbeda tidak bisa digabungkan, karena seolah-olah azas wakaf telah kehilangan identitas individual waqîf-nya.

Sayangnya, kemanfaatan wakaf ini belum secara optimal didapatkan, karena selama ini kemanfaatan wakaf hanya masih seputar di rumah ibadah, madrasah, dan makam. Jika dilihat dari segi keagamaan, semangat ini tentunya sungguh sangat baik, karena keberadaan wakaf yang ada dapat dimanfaatkan sebagai tempat ibadah, belajar, dan sebagainya. Sehingga pada akhirnya akan

\footnotetext{
${ }^{3}$ Abû Husayn Muslim ibn Hajjâj al-Qusyayrî al-Naysaburî, Shah $\underline{\text { Hh }}$ Muslim, terj. Adib Bisri Mustofa (Semarang: al-Syifâ', 1993), juz 4, hlm. 181.
} 
mampu meningkatkan keimanan umat Muslim. Namun apabila dilihat dari segi ekonomisnya, potensi keberadaan wakaf masih jauh dari yang diharapkan.

Tetapi, akhir-akhir ini kita sering mendengar istilah baru, yaitu cash waqf, atau yang lazim diterjemahkan dengan wakaf tunai. Sebenarnya inti persoalan dalam cash waqf adalah obyeknya yang berupa uang, sehingga terjemahan yang lebih tepat adalah wakaf uang.

Kehadiran wakaf uang diharapkan dapat menjadi media rekonstruksi sosial dan pembangunan, sehingga mayoritas penduduk dapat berpartisipasi untuk mewujudkan partisipasi tersebut, maka berbagai upaya pengenalan tentang arti pentingnya wakaf uang sebagai sarana menggerakkan roda perekonomian umat Muslim. Telah banyak penelitian historis yang dilakukan oleh para pakar tentang fungsi wakaf dalam berbagai sektor kehidupan umat. Michael Dumper menyimpulkan bahwa di Timur Tengah, pada masa klasik Islam dan pertengahan, institusi wakaf telah memainkan peran yang sangat penting dalam sejarah kaum Muslim dalam membangun kesejahteraan rakyat. ${ }^{4}$

\section{Wakaf Uang dalam Perspektif Hukum Islam}

Kata wakaf atau waqf berasal dari bahasa Arab yang berasal dari akar kata wa-qa-fa berarti menahan, berhenti, diam di tempat atau berdiri. Kata waqafa-yaqifu-waqfan semakna dengan kata habasa-yahbisu-tahbîsan yang maknanya terhalang untuk menggunakan. Kata waqf dalam bahasa Arab mengandung makna menahan, menahan harta untuk diwakafkan, tidak dipindahmilikkan. ${ }^{5}$

Pengertian wakaf dalam arti berdiam di tempat, jika dikaitkan dengan wuqûf artinya adalah berdiam di 'Arafah pada tanggal 9 dzulhijjah pada pelaksanaan ibadah haji. Sedangkan wakaf dengan pengertian mencegah atau menghentikan dapat dihubungkan dalam ilmu tajwid yang berarti apabila terdapat sebuah tanda waqaf,

\footnotetext{
4 Michael Dumper, Wakaf Muslimin di Negara Yahudi (Jakarta: Penerbit Lentera, 1994), hlm. 1 .

${ }^{5}$ Muhammad ibn Bakr ibn Mandzûr al-Mishrî, Lisân al-'Arab (Bulaq: al-Mishriyah, $1301 \mathrm{H})$, Jilid 11, hlm. 276.
} 
maka orang yang membaca al-Qur'an harus menghentikan bacaannya, baik sekedar untuk mengambil nafas maupun menghentikan bacaan seterusnya. Sedangkan pengertian wakaf dalam pengertian menahan apabila dihubungkan dengan harta kekayaan seseorang, maka pengertian inilah yang disebut dengan wakaf. 6

Dalam bahasa Arab, istilah wakaf kadang-kadang bermakna objek atau benda yang diwakafkan (al-mawqûff bih) atau dipakai dalam pengertian wakaf sebagai institusi seperti yang dipakai dalam perundang-undangan Mesir. Di Indonesia, terma wakaf dapat bermakna objek yang diwakafkan atau institusi. ${ }^{7}$

Sedangkan menurut istilah para ulamâ' agak berbeda redaksi dalam memberikan rumusan, ada yang menyatakan bahwa wakaf adalah penahanan harta benda yang dapat diambil manfaatnya tanpa musnah seketika dan untuk penggunaan yang mubah serta dimaksud untuk mendapatkan keridhaan Allah swt. ${ }^{8}$

Dalam pengertian secara istilah lainnya, wakaf adalah sejenis pemberian yang pelaksanaannya dilakukan dengan jalan menahan pemilikan asal (tahbisul ashli), lalu menjadikan manfaatnya itu agar tidak diwariskan, dijual, dihibahkan, digadaikan, disewakan, dan sejenisnya. Sedangkan cara pemanfaatannya adalah menggunakan sesuai dengan kehendak pemberi waqaf tanpa imbalan. ${ }^{9}$

Abû Hanîfah memberikan definisi wakaf sebagaimana yang dikutip oleh Wahbah al-Zuhayli, bahwa wakaf adalah penghentian benda tidak bergerak dari pemilikan waqîf secara hukum dan menyedekahkan manfaatnya untuk kepentingan umum. ${ }^{10}$

Sedangkan jumhur ulamâ', termasuk di dalamnya sahabat Abû Hanîfah, yakni Abû Yûsuf dan Muhammad alSyâfi'îyah dan golongan Hanabilah, wakaf adalah menahan harta yang memungkinkan diambil manfaatnya, tetap wujudnya, dan

6 Sayyid Sâbiq, Fiqh al-Sunnah (Beirut: Dâr al- Fikr, tt.), juz 3, hlm. 515.

7 Juhaya S. Praja, Perwakafan di Indonesia: Sejarah, Pemikiran, Hukum, dan Perkembangannya (Bandung: Yayasan Piara, 1995), hlm. 6.

8 Ahmad Azhar Basyir, Asas-asas Hukum Mual'amalat (Hukum Perdata Islam) (Yogyakarta: Fakultas Hukum UII, 1993), hlm 18.

9 Depag RI, Paradigma Baru Waqaf di Indonesia (Jakarta: Direktorat Jenderal Bimbingan Masyarakat Islam, 2007), hlm. 1.

10 al-Zuhayli, Fiqh al-Islâm, hlm. 153 
dibelanjakan waqîf untuk mendekatkan diri kepada Allah. Dengan diwakafkannya itu, harta keluar dari pemilikan waqîf dan harta tersebut secara hukum milik Allah. Bagi waqîf terhalang untuk memanfaatkannya dan wajib mendermakan hasilnya sesuai tujuan. ${ }^{11}$

Sedangkan menurut golongan Mâlikiyyah, sebagaimana yang dikutip oleh Wahbah al-Zuhayli, wakaf mempunyai arti bahwa pemilik harta memberikan manfaat harta yang dimiliki kepada mustahiq. Menurut mereka, harta tersebut dapat berupa benda yang disewa kemudian hasilnya diwakafkan. ${ }^{12}$

Dari beberapa pendapat di atas, terdapat kejelasan mengenai prinsip wakaf menurut para ulama' termasuk ulama Hanafiyah yang berpendapat bahwa syarat benda yang diwakafkan adalah bendabenda tidak bergerak, hanya benda-benda bergerak tertentu saja yang boleh diwakafkan yakni benda-benda yang memenuhi syarat yang sudah dikemukakan dan jenis-jenis benda yang sudah diwakafkan oleh para sahabat. Dengan demikian, pembahasan ulamâ' tentang wakaf sebenarnya mengalami dinamisasi, dibuktikan dengan munculnya beberapa hasil ijtihâd yang mereka sampaikan untuk mengantisipasi perkembangan zaman.

Dalam madzhab Mâlikiyah ada pendapat yang membolehkan mewakafkan manfaat hewan untuk dipergunakan dan mewakafkan uang. Sementara, menurut ulama madzhab Syâfi'îyah dan Hanabilah bahwa baik harta bergerak (seperti mobil dan hewan), maupun harta tidak bergerak (seperti rumah dan tanaman) boleh diwakafkan. Sedangkan ulama Hanafiyah, sebagaimana dikutip Wahbah alZuhayli13, memperbolehkan wakaf uang sebagai pengecualian karena sudah banyak dilakukan masyarakat, dengan kata lain madzhab Hanafi menetapkan berdasarkan dalil 'urf. 14 Melihat pemikiran ulamâ' di atas, dapat diketahui dengan jelas bahwa ada ijtihâd ulamâ' tentang wakaf yang terkesan agak kaku, namun ada juga yang sudah terlihat dinamis.

Dalam catatan sejarah Islam, wakaf uang ternyata sudah dipraktikkan sejak awal abad kedua hijriyah. Ada sebuah riwayat

11 Muhammad Abû Zahrah, Muhâdlarât fî al-Waqf (Kairo: Dâr al-Fikr al-'Arabi, 1971), hlm. 41.

12 al-Zuhayli, Fiqh al-Islâm, hlm. 155

13 Ibid, hlm. 163.

14 Ibid, hlm. 154-157. 
yang menyatakan bahwa al-Zuhri berpendapat dianjurkan wakaf dinar dan dirham untuk pembangunan sarana dakwah, sosial, dan pendidikan umat Muslim. Ada pun caranya adalah dengan menjadikan uang tersebut sebagai usaha kemudian menyalurkan keuntungannya sebagai wakaf. ${ }^{15}$ al-Zuhri juga menyatakan bahwa boleh mewakafkan dinar dan dirham dengan cara menjadikan dinar dan dirham tersebut sebagai modal usaha (dagang) kemudian menyalurkan keuntungan sebagai wakaf. ${ }^{16}$

Dalam madzhab Hanafiyyah, pada dasarnya wakaf diperuntukkan untuk barang tidak bergerak, seperti tanah, pekarangan, dan bangunan. Wakaf terhadap benda bergerak diperbolehkan jika ada salah satu dari tiga syarat, yakni; mengikuti benda tak bergerak, ada nash yang mengatur secara spesifik, dan telah berlaku' urf.

Syarat pertama, yakni mengikuti benda bergerak, diajukan oleh kalangan Hanafiyyah karena pada dasarnya wakaf diperuntukkan kepada benda tidak bergerak. Karena di atas barang bergerak tersebut ada benda bergerak yang merupakan bagian darinya, maka wakaf benda bergerak tersebut sah, sesuai dengan kaidah fiqhiyyah, al-tâbi' tâbi17, artinya benda yang ada pada pokok berlaku hukumnya mengikuti benda pokok.

Syarat kedua, ada nash yang mengatur secara spesifik, pada dasarnya merupakan pengecualian dari wakaf benda tak bergerak. Wakaf model kedua ini bersifat ta'abbudi karena diatur khusus oleh nash. Seperti hadits yang diriwayatkan oleh imam al-Bukhârî:

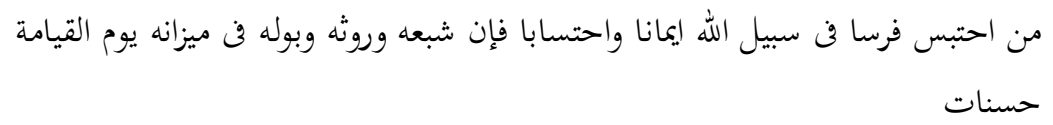

"Barang siapa mewakafkan kuda untuk kepentingan sabilillah karena didasari iman dan mengharap pahala dari Allah, maka

15 Depag RI, Strategi Pengembangan Wakaf Tunai di Indonesia (Jakarta: Direktorat Jenderal Bimbingan Masyarakat Islam, 2001), hlm. 135

16 Al-Su'ûd Muhammad, Risâlah fi Jawâz al-Waqf al-Nuqûd (Beirut: Dâr Ibn Hazm, tt.), hlm. 10.

17 'Ali Ahmad al-Nadawî, al-Qawâ'id al-Fiqhiyyah (Damaskus: Dâr al-Qalam, 1991), hlm. 363. 
makanan, kotoran, dan kencingnya kuda tersebut akan berubah menjadi amal baiknya di hari kiamat". 18

Dalam hadits lain juga disebutkan bahwa

$$
\text { أن رسول الله صلى الله عليه وسلم قال : أما خالد فقد احتبس أدراعه وأعتاده في سبيل الله }
$$

"Sedangkan Khâlid ibn Walîd telah mewakafkan baju besi dan peralatan perangnya". 19

Syarat ketiga, bahwa benda yang tidak masuk dalam kategori tâbi' dan tidak ada nash khusus yang mengaturnya, seperti uang, peralatan rumah tangga, perahu, buku, dan perlengkapan jenazah, dimasukkan dalam persyaratan ketiga yakni adanya praktik tersebut di masyarakat. Pada dasarnya, persyaratan ketiga ini merupakan operasionalisasi dari dalil istiḩsân yang dikembangkan oleh mereka. Sebagaimana diketahui, bahwa Abû Hanîfah adalah penggagas dalil istiḩsân, yaitu mengunggulkan dalil yang satu dari dalil yang lainnya yang ada atau mengamalkan dalil yang paling kuat di antara dua dalil. Artinya adalah meninggalkan pemikiran (qiyâs) terhadap hukum sebuah masalah dengan mengambil dalil yang paling khusus. ${ }^{20}$

Dalam pengertian lain istiḩsân adalah meninggalkan qiyâs jalî menuju pengamalan (penggunaan) qiyâs khafi karena ada nilai mashlahah yang ingin diadakan. Ada beberapa bentuk istiḩsân, yaitu; istih̆sân bi al-nash, istiḩsân bi al-ijmấ', istiḩsân bi al-'âdah aw al-'urf, istiḩsân bi al-dlarûrah, istiḩsân bi al-qiyâs al-khafì, dan istihsân bi almashlahah. Tetapi dalam konteks ini, jenis istihsân yang digunakan adalah istihssân bi al-'âdah aw al-'urf 21 berdasarkan hadits yang diriwayatkan oleh Abdullâh bin Mas'ûd:

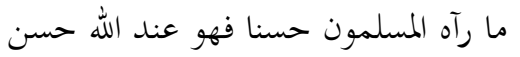

${ }^{18}$ Abu 'Abdillah Muhammad bin Isma'il al-Bukhâri, Shahîh al-Bukhârî (Beirut: Dâr alKitab al-Islâmi, tt.), juz 4, hlm. 34.

19 Ibid, juz 2 hlm. 534

${ }^{20}$ Abdullâh ibn Ahmad ibn Qudâmah al-Muqaddasi, Rawdlah al-Nâzhir wa Jannat alMunâzhir (Riyadh: Universitas Muhammad bin Sa'ûd, 1399 H), hlm. 162.

${ }^{21}$ Wahbah al-Zuhayli, Ushûl al-Figh Islamî (Beirut: Dâr al-Fikr, 1997), hlm. 743-746. 
"Sesuatu yang dianggap baik oleh kaum muslimin adalah baik menurut Allah".22

Hal ini juga sejalan dengan kaidah fiqhiyyah:

$$
\text { الثابت بالعرف كالثابت بالنص }
$$

"Ketetapan hukum berdasarkan 'urf seperti ketetapan hukum berdasarkan nash". ${ }^{23}$

Ada sebuah analisis yang cukup menarik diungkapkan oleh Ibn 'Âbidin dalam bukunya Radd al-Mukhtâr. Kalau selama ini perdebatan tentang wakaf uang versi Hanafiyyah menggunakan jalur 'urf sebagaimana penjelasan di atas, maka di samping jalur ini, dia juga menggunakan jalur lain. Menurutnya, uang dapat dibedakan antara nilai nilai instrinsik dan ekstrinsik. Nilai instrinsik adalah nilai bendanya yang berupa kertas, emas, perak, atau besi. Sedang nilai ekstrinsik adalah nilai dibalik simbol yang tertulis dalam mata uang tersebut. Berdasarkan pemilahan ini, maka dalam sebuah mata uang yang berubah ketika dimanfaatkan hanyalah wujud instrinsiknya. Sedang nilai ekstrinsiknya tetap abadi (baqa'), dan dapat dipindahtangankan. Perubahan wujud lahirnya tidak akan mengganggu nilai ekstrinsik, karena dengan mudah dapat digantikan oleh mata uang lain. Karena itulah, menurutnya, wakaf uang adalah sesuatu yang sah.24

Dari uraian di atas dapat dinyatakan bahwa secara ekonomi sesungguhnya wakaf uang sangat potensial untuk dikembangkan di Indonesia, karena dengan model wakaf ini daya jangkauan mobilisasinya akan jauh lebih merata kepada sebagian anggota masyarakat dibandingkan dengan model wakaf dalam bentuk harta fisik seperti yang biasa dilakukan oleh umat Muslim selama ini, seperti wakaf tanah dan bahan bangunan.

\section{Manfaat dan Peluang Wakaf Uang}

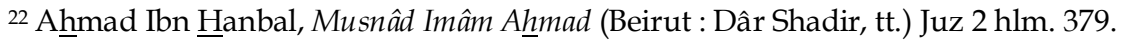

23 al-Nadawi, al-Qawấ'id al-Fiqhiyyah, hlm. 256-265.

${ }^{24}$ Muhammad Amîn Ibn 'Âbidin, Radd al-Mukhtâr (Beirut: Dâr al-Kutub al-'Ilmiyyah, tt.), hlm. 554-555.
} 
Pada umumnya, wakaf selama ini dikenal terkait dengan sumbangan berupa aset tetap (property of permanent) oleh seorang Muslim dengan tujuan murni ketaqwaan. Namun, belakangan wakaf uang mendapat perhatian serius, karena ternyata juga memiliki akar yang panjang dalam sejarah Islam. Sedang wakaf uang sebagai instrumen keuangan sungguh merupakan suatu produk baru dalam sejarah perbankan Islam. Pemanfaatan wakaf uang dapat dibedakan menjadi dua, yakni pengadaan barang privat dan barang sosial.

Karena itu, wakaf uang membuka peluang yang unik bagi penciptaan investasi di bidang keagamaan, pendidikan, dan pelayanan sosial. Tabungan dari warga yang berpenghasilan tinggi dapat dimanfaatkan melalui penukaran sertifikat wakaf uang. Sedangkan pendapat yang diperoleh dari pengelolaan wakaf uang dapat dibelanjakan untuk berbagai tujuan, misalnya untuk pemeliharaan harta-harta wakaf. ${ }^{25}$

Kegiatan investasi sosial berupa wakaf uang akan dapat menciptakan landasan bagi terselenggaranya pemupukan modal sosial secara permanen dan dapat dimanfaatkan untuk membantu terlaksananya kredit program yang akan memperkokoh bagi terciptanya landasan moral dan sosial bagi terciptanya kesejahteraan masyarakat. ${ }^{26}$

Ada beberapa manfaat dalam pembelian sertifikat wakaf uang yang dapat dilakukan dengan maksud untuk memenuhi target investasi, sedikitnya empat bidang: Pertama, kemanfaatan bagi kesejahteraan pribadi (dunia-akhirat). Wakaf uang termasuk salah satu amal jâriyah yang terus mengalir pahalanya. Wakaf uang sebagai sedekah jâriyah memainkan peranan penting bagi seseorang untuk mencapai kesejahteraan dunia dan akhirat. Kedua, kemanfaatan bagi kesejahteraan keluarga (dunia-akhirat). Sertifikat wakaf uang dapat juga dibeli untuk menjamin perbaikan kwalitas hidup generasi penerus melalui pelaksanaan program pendidikan, penikahan, dan lain-lain. Sebab bank akan tetap bertanggung jawab untuk mengelola profit dari sertifikat wakaf uang itu karena dengan cara pengelolaan program seperti itu, maka wakaf uang dapat dimanfaatkan untuk kesejahteraan generasi mendatang.

25 Depag RI, Strategi Pengembangan Wakaf Tunai,hlm. 59-60.

26 Ibid, hlm. 62 
Ketiga, pembangunan sosial. Dengan profit dari wakaf uang, seseorang dapat memberi bantuan yang berharga bagi pendirian ataupun operasionalisasi lembaga-lembaga pendidikan termasuk masjid, madrasah, rumah sakit, sekolah, kursus, akademi, dan universitas. Keempat, membangun masyarakat sejahtera. Dana yang terhimpun dari wakaf uang akan diinvestasikan dan hasilnya dapat memberikan jaminan sosial kepada si miskin dan keamanan bagi si kaya. Akhirnya, wakaf uang akan menjadi wahana bagi terciptanya kepedulian dan kasih sayang anatara si kaya dan si miskin, sehingga membantu terciptanya hubungan yang harmonis dan kerjasama yang baik. ${ }^{27}$

Wakaf uang juga membuka peluang yang unik bagi penciptaan investasi di bidang ekonomi, termasuk di dalamnya bidang keagamaan, pendidikan, dan pelayanan sosial. Bank-bank syari'ah dapat menghimpun dana dari anggota masyarakat yang berpenghasilan tinggi yang akan memberikaan wakaf uangnya dengan menerbitkan Sertifikat Wakaf uang (SWU). Selanjutnya, pendapatan yang diperoleh dari pengelolaan wakaf uang tersebut dapat dibelanjakan untuk berbagai tujuan yang beberapa di antaranya untuk pemeliharaan harta-harta wakaf itu sendiri serta pengeliaran-pengeluaran investasi ekonomi lainnya.

Selain manfaat tersebut di atas, ternyata masih terdapat manfaat wakaf uang yang lebih besar dan lebih riil yaitu: Pertama, wakaf uang jumlahnya bisa bervariasi, sehingga seseorang yang memiliki dana terbatas sudah bisa mulai memberikan dana wakafnya tanpa harus menunggu menjadi tuan tanah terlebih dahulu. Kedua, melalui wakaf uang, aset-aset wakaf yang berupa tanah-tanah kosong bisa mulai dimanfaatkan dengan pembangunan gedung atau diolah untuk lahan pertanian. Ketiga, dana wakaf uang juga bisa membantu sebagian lembaga-lembaga pendidikan Islam yang cash flow-nya terkadang kembang-kempis dan menggaji sivitas akademika ala kadarnya. Keempat, umat Muslim dapat lebih mandiri dalam mengembangkan dunia pendidikan tanpa harus terlalu tergantung

27 M.A. Mannan, Sertifikat Wakaf Tunai: Sebuah Inovasi Intrumen Keuangan Islam, terj. Tjasmijanto dan Rozidyanti (Jakarta: CIBER dan PKTTI UI, tt.), hlm. 49 
pada anggaran pendidikan negara yang memang semakin lama semakin terbatas. ${ }^{28}$

Melihat manfaat dari wakaf uang di atas, tidak menutup kemungkinan adanya peluang besar dalam mengelola dan upaya memberdayakan wakaf tersebut. Oleh karena itu, diperlukan sebuah konsep figh wakaf yang fleksibel, yaitu terbuka terhadap penafsiranpenafsiran baru, dinamis, sehingga wakaf merupakan potensi yang cukup besar untuk dikembangkan sesuai dengan kebutuhan zaman.

Peluang lainnya adalah jumlah penduduk Muslim kelas menengah ke atas di Indonesia merupakan potensi yang sangat besar untuk merealisasikan wakaf uang ini. Perlu juga dilihat adaya pertumbuhan minat masyarakat untuk menggali potensi sistem ekonomi syari'ah. Mulai bermunculan lembaga-lembaga ekonomi dan keuangan syari'ah yang mendidik sumber daya manusia yang berkualitas baik, bersamaan dengan semangat yang tinggi untuk menerapkan sistem ekonomi syari'ah. ${ }^{29}$

Setelah melihat adanya peluang wakaf uang untuk dikelola dan diberdayakan di Indonesia, bukan berarti tidak ada tantangantantangan yang menghadang, bukan untuk dihindari tetapi untuk dipikirkan secara matang dalam memanajemen tantangan tersebut.

Adapun tantangan dalam mengelola dan memberdayakan wakaf uang adalah sebagai berikut: Pertama, terdapat kebekuan pemikiran umat Muslim terhadap paham wakaf, seperti keyakinan sebagian umat Muslim bahwa harta wakaf tidak boleh ditukar dengan alasan apapun, kebanyakan masyarakat mempercayakan harta wakafnya kepada seseorang yang dianggap tokoh dalam lingkungannya yang tidak diketahui persis kemampuannya dalam urusan wakaf, dan harta yang diwakafkan biasanya adalah harta yang tidak bergerak. Masyarakat kelas menengah atas masih fanatik terhadap wakaf harta tak bergerak, sehingga sulit untuk berpindah ke wakaf uang. Kedua, perlu diketahui juga bahwa kebanyakan nadzîr wakaf masih tradisional, seperti nadzîr wakaf masjid, mushalla, madrasah, dan tanah kuburan. Ketiga, tantangan berikutnya adalah

28 Muhammad Syafi'i Antonio, Cash Waqf dan Anggaran Pendidikan dalam Kumpulan Hasil Seminar Perwakafan (Jakarta: Depag RI, 2004), hlm. 212.

29 Achmad Djunaidi dan Thobieb Al-Asyhar, Menuju Era Wakaf Produktif (Depok: Mumtaz Publishing, 2007), hlm. 65-86. 
adanya pengaruh krisis ekonomi politik dalam negeri. ${ }^{30}$ Untuk itu, diperlukan seseorang maupun lembaga pemerintah atau swasta yang bisa dijadikan panutan untuk mengalihkan kebiasaan mewakafkan harta tidak bergerak menuju wakaf uang. Pengalihan ini membutuhkan proses yang tidak sebentar.

Dalam maqâshid syarî'ah terhadap diberlakukannya wakaf, terutama wakaf uang, adalah adanya kehendak agar harta wakaf itu tidak boleh diam. Apabila semakin banyak hasil harta wakaf yang dapat dirasakan dan dikelola dengan baik oleh orang lain, maka diharapkan semakin besar pula pahala yang akan mengalir kepada pihak waqîf. Oleh karenanya, dana yang dikumpulkan melalui wakaf uang nantinya akan dikelola oleh suatu manajemen investasi. Manajemen investasi dalam hal ini bertindak sebagai nadzîr (pengelola dana wakaf) yang akan bertanggung jawab terhadap pengelola harta wakaf.

Yang tidak kalah penting adalah harus ada optimalisasi pendidikan dan sosialisasi wakaf uang, pengembangan wakaf uang menjadi wakaf properti dan penerapan kebijakan pemerintah minimal melalui Peraturan Daerah-Peraturan Daerah bernuansa syarî'ah baik tingkat kabupaten maupun provinsi yang mayoritas penduduknya beragama Islam adalah strategi penting yang perlu diperhatikan dalam mengembangkan wakaf uang ke depan. Di sinilah akan dapat dibuktikan bahwa wakaf uang adalah salah satu elemen penting dalam keuangan ekonomi syari'ah. Untuk menjaga tingkat profesionalisme nâzhir, sudah saatnya nâzhir mempunyai sertifikasi dari lembaga sertifikasi wakaf.

Inilah saatnya umat Muslim di Indonesia mewujudkan gerakan nasional wakaf uang. Untuk lebih mudah dalam mewujudkannya, gerakan nasional wakaf uang ini dibutuhkan kerja sama dengan pihak-pihak lain yang memiliki hubungan permodalan usaha, nâzhir wakaf harus mensinergikan program-program usahanya dengan Majelis Ulama Indonesia (MUI), perguruan tinggi, lembaga keuangan nasional, lembaga konsultan keuangan, lembaga manajemen nasional, lembaga konsultan hukum dan lembaga lainnya.

30 Ibid, hlm. 47-59 
Wakaf Uang

\section{Penutup}

Wakaf uang memiliki fleksibilitas dan nilai kemashlahatan yang besar yang mungkin tidak dimiliki oleh benda lain. Sehingga dalam mengelola dan mengembangkan wakaf uang ini dibutuhkan sumber daya manusia yang jujur, amanah, profesional, mempunyai integritas, mempunyai wawasan ilmu ekonomi, dan mempunyai komitmen kuat. Karena wakaf uang ini termasuk pendapat baru di Indonesia, hendaknya digalakkan sosialisasi yang berkelanjutan baik oleh akademisi, ulama, praktisi ekonomi syarî́ah baik melalui seminar, ceramah, khutbah jum'at, training maupun tulisan di media massa. Sehingga masyarakat tidak lagi asing mendengar istilah baru ini, dan masyarakat tidak ragu lagi untuk mengalihkan bentuk wakaf dari benda yang tidak bergerak menuju wakaf uang.

\section{Daftar Pustaka:}

'Âbidin, Muhammad Amîn Ibn. Radd al-Mukhtâr. Beirut: Dâr al-Kutub al-'Ilmiyyah, tt.

Antonio, Muhammad Syafi'i. Cash Waqf dan Anggaran Pendidikan dalam Kumpulan Hasil Seminar Perwakafan. Jakarta: Depag RI, 2004.

Basyir, Ahmad Azhar. Asas-asas Hukum Mual'amalat. Hukum Perdata Islam). Yogyakarta: Fakultas Hukum UII, 1993.

Basyir, Ahmad Azhar. Hukum Islam tentang Wakaf, Ijarah, Syirkah. Bandung: PT al-Ma'arif, 1977.

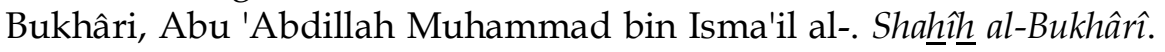
Beirut: Dâr al-Kitab al-Islâmi, tt.

Depag RI, Paradigma Baru Waqaf di Indonesia. Jakarta: Direktorat Jenderal Bimbingan Masyarakat Islam, 2007.

Depag RI, Strategi Pengembangan Wakaf Tunai di Indonesia. Jakarta: Direktorat Jenderal Bimbingan Masyarakat Islam, 2001.

Djunaidi, Achmad dan Al-Asyhar, Thobieb. Menuju Era Wakaf Produktif. Depok: Mumtaz Publishing, 2007.

Hanbal, Ahmad Ibn. Musnâd Imâm Aḥmad. Beirut: Dâr Shadir, tt.

Mannan, M.A. Sertifikat Wakaf Tunai: Sebuah Inovasi Intrumen Keuangan Islam, terj. Tjasmijanto dan Rozidyanti. Jakarta: CIBER dan PKTTI UI, tt. 
Michael Dumper, Wakaf Muslimin di Negara Yahudi. Jakarta: Penerbit Lentera, 1994.

Mishrî, Muhammad ibn Bakr ibn Mandzûr al-. Lisân al-'Arab. Bulaq: al-Mishriyah, $1301 \mathrm{H}$.

Muhammad Abû Zahrah, Muhâdlarât fî al-Waqf. Kairo: Dâr al-Fikr al'Arabi, 1971.

Muhammad, al-Su' ûd. Risâlah fi Jawâz al-Waqf al-Nuqûd. Beirut: Dâr Ibn $\underline{\text { Hazm, }}$ tt.

Muqaddasi, Abdullâh ibn Ahmad ibn Qudâmah al-. Rawdlah alNâzhir wa Jannat al-Munâzhir. Riyadh: Universitas Muhammad bin Sa'ûd, $1399 \mathrm{H}$.

Muslim, Abû Husayn, ibn Hajjâj al-Qusyayrî al-Naysaburî. Shahîh $\underline{h}$ Muslim, terj. Adib Bisri Mustofa. Semarang: al-Syifâ', 1993.

Nadawî, 'Ali Ahmad al-. al-Qawấ'id al-Fiqhiyyah. Damaskus: Dâr alQalam, 1991.

Praja, Juhaya S. Perwakafan di Indonesia: Sejarah, Pemikiran, Hukum, dan Perkembangannya. Bandung: Yayasan Piara, 1995.

Sâbiq, Sayyid. Figh al-Sunnah. Beirut: Dâr al- Fikr, tt.

Zuhayli, Wahbah al-. Figh al-Islâm wa Adillatuh. Mesir: Dâr al-Fikr, tt.

Zuhayli, Wahbah al-. Ushûl al-Figh Islamî. Beirut: Dâr al-Fikr, 1997. 